\title{
Chapter 7 \\ Migrant Status and Lone Motherhood - Risk Factors of Female Labour Force Participation in Switzerland
}

\author{
Nadja Milewski, Emanuela Struffolino, and Laura Bernardi
}

\section{Introduction}

The focus of this chapter is labour market participation among lone immigrant mothers in Switzerland. Lone immigrant mothers are exposed to four stratification risks on the labour market. First, women are generally disadvantaged relative to men. Second, mothers of young children are less active on the labour market than women in general (Boeckmann et al. 2015). Third, lone mothers who work may experience particularly high levels of role incompatibility as workers and primary care-givers. Fourth, international migrants have fewer labour market opportunities than non-migrants, and this disadvantage continues into the second generation (e.g., Constant and Massey 2005).

Despite the fact that they are exposed to multiple risk factors, lone parenthood among international migrants has not received much attention in the literature. Little is known about the patterns, the determinants, and the consequences of lone motherhood among migrant populations, including about their labour market activity. There are several possible reasons for this research gap, such as that the integration literature has focused mainly on male migrants, as men were assumed to be the initial migrants and the economically (more) important members of migrant families (Lutz 2007; Pries 2010; Charsley 2012). Studies in family demography have mainly focused on the processes of family formation among immigrants living in

\footnotetext{
N. Milewski $(\bowtie)$

University of Rostock, Rostock, Germany

e-mail: nadja.milewski@uni-rostock.de

E. Struffolino

WZB Berlin, Humboldt University, Berlin, Germany

L. Bernardi

National Centre of Competence in Research LIVES - Overcoming Vulnerability: Life course perspectives (NCCR Lives), University of Lausanne, Lausanne, Switzerland
} 
western Europe: i.e., union formation, marriage, transition to the first birth, and subsequent childbearing.

Only in recent years has union dissolution among migrants become a topic in demographic studies on immigrant groups living in western European countries (Kulu and Gonzáles-Ferrer 2014). The literature on family formation suggests that lone parenthood has been rather rare among immigrant groups, because, for example, international migration policies tend to favour married family migrants. Therefore, the share of people who are married has long been higher among migrant groups than among the non-migrant population in the respective destination country. Union stability among immigrants has also been rather high due to their high marriage rates and relatively large numbers of children. Rates of extra-marital childbearing and of divorce have been low in immigrant populations (e.g., Milewski and Kulu 2014).

In recent years, however, the nature of immigration has changed. The percentage of women migrating - whether alone, as the breadwinner, or as the forerunner in the family - has increased (Lutz 2007). At the same time, the percentage of immigrant descendants in the total population has been rising in many western European countries. These processes of population change appear to be accompanied by tendencies among migrants to adapt to the demographic behavioural patterns of the host country: the trends towards non-marital cohabitation, extra-marital childbearing, and marriage/union dissolution that were observed in non-migrant populations some two decades earlier have recently been spreading to migrant groups (Staat and Wagenhals 1996). Consequently, lone parenthood is becoming increasingly common in migrant populations.

We examine the labour market activity patterns among immigrant mothers while taking into account their partnership status. Over time, the literature has showed consistently and with only a small amount of variation by country that lone mothers are, on average, at higher risk than partnered mothers of being poor, of being dependent on welfare, of being unemployed, of having low earnings, and of having high child care costs (Staat and Wagenhals 1996; Zagel 2014). We add to the literature by focusing on the intersection of partnership and migration status, and specifically by investigating whether being a lone mother and a migrant at the same time represents an additive risk for non-employment. We also account for within-group variation by differentiating between the immigrant generations. In addition, we explore the heterogeneity across migrants by their countries of origin.

We carry out our study on immigrant mothers living in Switzerland, a multilingual country with a long immigration history. On average, migrant women are more likely than non-migrant women to be in full-time employment when they work, and to be dependent on social welfare (Liebig et al. 2012). This is also the case in Switzerland, a country with an extremely diversified foreign-born population in terms of geographical origin, socio-economic position, and migration trajectory (Afonso 2004; Fibbi and Wanner 2009; Laganà et al. 2014). At the time of writing, the largest immigrant group in Switzerland is from Italy, followed by groups from Germany, Portugal, and the former Yugoslavia (FSO 2015). The last two groups are the most recent arrivals. The Portuguese migrants are mainly economic migrants from within the Schengen area of free labour market circulation. The migrants from 
the former Yugoslavia are rather heterogeneous: some are economic migrants, others are refugees who were fleeing forced army recruitment or ethnic persecution (especially from Kosovo), and more recent migrants came through family reunification. Today, the percentage of the country's population who are foreigners (i.e., who are not Swiss citizens) is about $22 \%$. About $27 \%$ of the total population of Switzerland are foreign-born; one of the highest shares in Europe (OECD 2015).

Overall, female labour force participation (FLFP) levels are rather high in Switzerland: about $81 \%$ of the native-born women and about $76 \%$ of the foreignborn women are employed (OECD 2015). However, because of the low availability of public child care and the resulting family-work conflicts, a large portion of women in Switzerland work part time (Bühlmann et al. 2012). Weak labour market attachment, poverty, and welfare dependency are major concerns in the sociopolitical debate about lone mothers (Salter 2017), as well as about migrants. Looking at the labour market situations of immigrant lone mothers can thus provide insights into the often precarious living conditions of mothers who are primary care-givers and income providers, and who may also face specific difficulties related to their immigrant status.

\section{Background}

\section{The Swiss Context and Lone Mothers' Employment}

According to official Swiss statistics for 2012, $15 \%$ of the households with at least one child under age 25 were one-parent households (FSO 2013). Individual data from the Enquête sur les familles et les générations (EFG) 2013 indicate that about $6 \%$ of the total population between ages 15 and 55 were lone mothers living with at least one biological child below the age of 18 (Struffolino and Bernardi 2016). While these numbers present a snapshot at the moment of the survey, retrospective data on the union and fertility histories of the women in the sample indicate that the prevalence of lone parenthood is higher: almost $13 \%$ of these respondents had experienced lone motherhood between 1953 and 2013. Some of these women "exited" lone parenthood because their children's biological father or a new partner moved into the household, while for others lone motherhood ended because their grown-up child(ren) left the household. A one-parent household has become a relatively common living arrangement that growing numbers of individuals are experiencing for durations ranging from a few months to several years (Struffolino and Bernardi 2016). The great majority of lone parents are women (89\% in 2000, cf. Bühler 2002) who become the primary care-giver and the main breadwinner of their family.

In Switzerland, the average income of lone parent households is far lower than that of other household types, with the exception of households of people aged 65+ who are living alone (OECD 2015). The high poverty risk faced by lone-parent households can be partially explained by the gendered structure of the labour mar- 
ket (Flückiger 1998; Branger 2003) and the disadvantages women experience when they are active in the labour market, including work-family conflicts and a tendency to work part time (FSO 2013).

On the one hand, Switzerland offers relatively widespread social policy protections against poverty (Bertozzi et al. 2005; Armingeon et al. 2004) and rather generous unemployment benefits (Gebel 2013). On the other hand, the care system is mostly relegated to private institutions, and the public policies targeting work-family reconciliation are less robust than those of other western welfare states (Monnier 2006): school schedules are hardly compatible with those of parents who work, and expensive public child care and marriage-based taxation discourage women's labour force participation (Bütler and Ruesch 2007). These welfare arrangements are based on the one-and-a-half-earner model, in which men work full time while women who become mothers adjust their working hours to accommodate their care obligations (Giraud and Lucas 2009). As a consequence, while Switzerland has a higher female labour market participation rate than many other European countries, most Swiss women are employed part time (Bühlmann et al. 2012).

“Despite women's inroads into employment and men's increasing participation in childcare, women remain primarily responsible for children. Thus, motherhood is an axis of inequality central to our understanding of the processes that shape women's employment patterns" (Boeckmann et al. 2015: 2). Lone mothers are likely to be particularly disadvantaged, because there is no partner in the household to compensate for their relatively low income (Stutz and Knupfer 2012). Therefore, the major challenge for women in Switzerland, where the care and work spheres are strongly gendered, is to increase their disposable income after making the transition to lone parenthood, while continuing to devote time to care. However, as social protections may cover the most immediate and urgent economic needs of lone mothers, those with unfavourable labour market prospects may have a lower incentive to take up paid work (Gangl 2006; Luijkx and Wolbers 2009; Dieckhoff 2011).

Hence, our first working hypothesis concerns the effect of the partnership status on labour market participation: Lone mothers are more likely to either work full time or to be out of employment than mothers who share their household with a partner (H1).

\section{The Role of the Migrant Status for Labour Market Participation}

The literature on the labour market activities of women of majority populations has mainly focused on women's efforts to reconcile work and family life, the wage gap between men and women, and the wage gap between women based on their motherhood status (e.g., Boeckmann et al. 2015). Although these studies took into account cultural factors by comparing different countries, most did not account for cultural heterogeneity within a single national population by controlling for immigrant status or citizenship.

In research on international migrants, structural integration is one of the most prominent research areas, with education and labour market being the most important and probably most frequently studied domains. The literature on labour market 
participation among international migrants has generally assumed that the crucial disadvantage faced by women is the high risk that they will be excluded from the labour market entirely; whereas the main disadvantages faced by men are the high risk of unemployment, of having a low income, and of having a low-level occupation due to various mechanisms of selection into migration and of integration (Algan et al. 2010; Höhne and Koopmans 2010).

For first-generation migrants' labour market integration of, human capitalunderstood as the set of worker's marketable skills in which workers make a variety of investments (Becker 1993) - plays a central role. According to the labour market assimilation theory (Chiswick 1978), immigrants may have initial disadvantages relative to non-migrants, though these disadvantages may vary by country of origin and destination; and these disadvantages may decrease or level off with increasing length of stay. The disadvantages are mainly related to the devaluation of foreign educational degrees, the relatively low host-country specific knowledge (e.g., the language proficiency), the negative selection into migration, and the preferences of migrants and their motivations for return migration or intentions to stay; i.e., the intention to return is negatively associated with an investment in host countryspecific knowledge and skills (Kalter 2008; van Tubergen 2008).

For migrant women in western and southern European destination countries, the empirical evidence on their labour force participation tends to confirm the labour market assimilation theory. The migrants' FLFP rates increase with length of stay, and eventually reach about the same rates as those of the respective majority population (Rendall et al. 2010). The empirical evidence on the economic success of migrant women cannot fully be explained by this theory, however. Increasing attention has been paid to the role of the partner; i.e., the influence the husband's human capital has on his wife's labour market career (Lin 1999; van Tubergen 2008). The results of these studies were in line with new home economics and the household specialisation theory (Becker 1991), which states that household's members specialize in the production of commodities to maximize the household utility function, that is through the division of labour between the household and the labour market. Long (1980), for example, showed that the income of immigrant women in the US decreases with increasing length of stay: a woman may participate in the labour market immediately after migration, but gradually withdraw when her partner has gained host country-specific human capital and has improved his own status on the labour market. Duleep (1998) called this the "family investment hypothesis".

FLFP is an indicator for the integration of immigrant women and for cultural transformation processes, since the labour market activity of women is influenced by cultural and/or religious norms concerning gender roles, traditional patterns in FLFP in the respective country of origin, as well as the size and the structure of the family (Reimers 1985; Antecol 2000; Blau et al. 2013). Previous research on international migrant women has mainly been concerned with gender roles and the division of labour in the family, and the differences between the gendered employment patterns in the women's respective counties of origin and of destination. More recent work has taken into account within-group variation by differentiating between the immigrant generations and/or the respective countries of origin (e.g., Blau et al. 
2013; Milewski 2013). Studies that further differentiated the employment status or the type of work among immigrant women tended to focus on precarious job conditions, such as the informal sector in domestic services or prostitution (Han 2003).

The literature based on representative surveys paid little attention to immigrant lone mothers until very recently, given their relatively low numbers in the samples and the relative difficulties to perform detailed analyses on them (we will come back to this in section 3 of our paper, where we describe the data).

In Switzerland, the labour market participation patterns of immigrant women differ substantially from those of Swiss women: On the one hand, immigrant women have a much higher unemployment rate than Swiss women (9\% versus $2 \%$ ), though this difference may be partially due to inactivity among Swiss women, who may not search for a job if they are less attached to the labour market than migrant women (Winkelmann 2002). On the other hand, there are differences when we take into account the employment patterns: compared to their native-born peers, immigrant women are equally likely to be in full-time employment and less likely to be in parttime employment. For example, in 2009 among all women of working ages, the shares of women who were in full-time employment were $31 \%$ for native-born women and $32 \%$ for foreign-born women from lower-income countries; whereas the shares of women in part-time employment were $44 \%$ and $27 \%$, respectively (Liebig et al. 2012). Thus, the average difference in employment rates between native-born and foreign-born women from lower-income countries has been traced back to the higher rates of part-time employment among non-migrants (Liebig et al. 2012).

Nevertheless, evidence on skilled migrant women from Latin America, Asia, and south-eastern Europe from studies using qualitative methods has shown that most of these women could not use their social and cultural capital to establish themselves in the stronger segments of the labour market, and that a considerable share of them are either excluded from the labour market or employed in jobs for which they are overqualified. Only one-third of these women report working at their skill level, and then only irregularly (Riaño and Baghdadi 2007). The evidence on the wage differentials between immigrants and non-migrants is contradictory, which suggests that the size of the gap varies depending on the migrant group and their composition by education. These differentials are substantially smaller among second-generation migrants (de Coulon 2003). A recent investigation on the positions of immigrants in the labour market in Switzerland concluded that the size of the gap between migrants and Swiss natives mostly depends on the migrant group and on whether the migrants completed their education before or after arriving in Switzerland (first-generation migrants). Differences in the labour market positions of natives and migrants tend to fade among second-generation migrants (Guarin and Rousseaux forthcoming). Other studies emphasize variation by country of origin though (Laganà et al. 2014).

Based on the theoretical considerations and the previous evidence on the labour market participation patterns of immigrant women, we have formulated hypotheses concerning their participation/non-employment levels and types of labour market activity by taking into account their employment hours: (H2) following the human capital approach, we assume that non-employment rates are higher among migrant lone mothers than among non-migrants due to the general disadvantages of migrants in the labour market. Among those who are gainfully employed, we expect to find 
that migrants on average work longer hours than non-migrants due to their lower wage returns.

Moreover, we expect to find variation between migrant groups; i.e., that the employment patterns vary between first-generation migrants and their descendants, as well as between migrants based on their country of origin: (H3) in line with the human capital approach, we assume that the FLFP patterns of second-generation migrants are more similar to those of non-migrants than to those of the first generation, since their host country-specific education and knowledge levels are higher than those of the first generation (Becker 1991; van Tubergen 2008).

\section{Socio-demographic Factors}

Finally, we consider what role individual and household characteristics play in shaping the differences between lone mothers and mothers in couples, as well as between migrants and non-migrants: if there are any differences in the employment patterns of the respective groups, we expect to find that they are smaller when we control for the composition of these groups; i.e., for the socio-economic characteristics of the mother and the household characteristics (H4) (Laganà et al. 2014).

\section{Data and Methods}

\section{Data}

For our analyses we used data from the Swiss Labour Force Survey (SLFS). This cross-sectional survey collects information about labour market participation, and offers a sample size that is large enough to allow us to compare lone mothers and mothers in couples by migrant status. We used the 2008 wave, as this was the last wave in which the questions concerning the country of birth of the parents of the respondents were included. Thus, for the respondents of the survey waves from 2009 onwards, we would have been unable to determine to which migrant generation they belonged. We selected all of the women who were between 20 and 54 years old and who were living with at least one child under age 18. We defined as lone mothers those mothers who were not sharing their household with a partner. Mothers in couples were defined as those who were sharing their household with a partner, irrespective of their marital status (and no matter whether the partner was the biological father of the children in the household).

The respondents in our sample were defined as non-migrants if they and both of their parents had been born in Switzerland, and as migrants (who were oversampled in the data) if they or either of their parents had been born outside of Switzerland. The final sample consisted of 4617 migrants and of 2197 non-migrants. In order to take into account within-group variation among migrants, we first distinguished between the migrant generations: individuals were defined as belonging to the first 
migrant generation if they were living in Switzerland in 2008 but had been born in another country to parents born abroad, and had migrated at age 15 or older. Secondgeneration migrants were defined as individuals who were either born in Switzerland to one or two parents born abroad, or who were born in another country to parents born abroad, and who had migrated before age 15. (The age used to distinguish between the migrant generations varies in the literature by research topic. In addition, the size of the respective sub-samples matters for statistical analyses. Since in Europe second-generation migrants tend to be rather young, we chose to group together those migrants who moved as children and those who were born in Switzerland. This seems appropriate for our research question since they all participated in public schooling in Switzerland, and lived there during childhood and/or adolescence. Hence, the second-generation migrants all experienced the Swiss societal context before the start of their reproductive years and of a labour market activity. Because the first-generation migrants had lived exclusively in their country of origin before age 15, their family formation behaviour may be more influenced by the context of their country of origin (Rumbaut 2004; de Valk and Milewski 2011).) About $70 \%$ of the migrants in our sample belonged to the first generation, while the remainder belonged to the second generation.

Second, we identified migrants according to their country of origin (without distinguishing between the migrant generations due to very small sample size for lone migrant mothers). The countries of origin were grouped into five categories: Switzerland (i.e., non-migrants), Western Europe (including Nordic countries), Eastern Europe, Southern Europe, and all other countries. If they were born in Switzerland, the country of origin of the second-generation migrants corresponds to their parents' country of origin. Such grouping reflects, as much as it was possible given the small sample size, the patterns of FLFP across regions, which are lowest in Mediterranean countries and highest Eastern Europe (Boeckmann et al. 2015).

Of the women in our sample, $10.5 \%$ were lone mothers and $89.5 \%$ were mothers in couples. These numbers are consistent with the census data from the Swiss statistical office on the family composition of households with at least one child (FSO 2015).

In our sample, $11 \%$ of the non-migrants and $10 \%$ of the migrants were lone mothers. Since there is no literature on this topic for migrants in Switzerland, we cannot compare these numbers with figures from other publications. We calculated, however, the respective numbers using two other longitudinal and representative datasets that contain immigrants living in Switzerland and non-migrants, and that are often used for family-related research questions: the Swiss Household Panel (SHP) and the Enquête sur les familles et les générations, a Swiss survey based on the Gender and Generation Survey (GGS) questionnaire design. Although these surveys provide a wide range of information on individuals' lives that we could not find in the SLFS data, their sample sizes for specific population groups are small. For both data sets we estimated consistent shares of lone parent families, but our samples were extremely small when we distinguished between non-migrants and migrants, and were even smaller when we tried to explore different migrant categories in greater depth. Given the lack of any kind of empirical evidence on lone parenthood and migrant background, we chose to use the SLFS, which provided us with a reasonably 
large sample size to empirically test our hypotheses. Yet, since the SLFS retrospectively collects employment and family data, the prevalence of ever-experiencing lone motherhood may be slightly higher (Struffolino and Bernardi 2016).

\section{Dependent Variables and Method}

We first ran a set of binomial logit regression models estimating the probability of being employed versus being out of employment ${ }^{1}$. We then carried out multinomial logit regression models in order to differentiate between the labour market participation levels; we estimated the probability of being unemployed/inactive, in fulltime employment ( $>90 \%$ of a 40 -hour working week), in long part-time employment $(50-89 \%)$, or in short part-time employment $(<50 \%)$. For both analyses, the independent variables of interest are the interaction between partnership status (mothers in couples or lone mothers) and a type of migrant background, operationalised as either the immigrant generation or the country of origin.

The results are displayed as predicted probabilities for the independent variables, and are to be interpreted as the linear probability connected to the respective category or the interaction of interest for all possible outcomes, net of the variables the models control for (Wooldridge 2002; Long and Freese 2014) ${ }^{2}$.

\section{Control Variables and Sample Description}

Following the literature on labour market participation among (lone) mothers (Baker et al. 1999; Boeckmann et al. 2015), we included a number of control variables and possible confounders of the main association under study (for descriptive statistics, see Table 7.1).

The first group of covariates were the individual characteristics of the respondent: age was used as a categorical variable (20-29, 30-35, 36-44, or 45+). The mean age of the migrants was 37 , and the mean age of the non-migrants was 38 . The women's educational background was captured by the highest level of education at the time of the interview (no or lower-secondary degree, upper-secondary degree, or

\footnotetext{
${ }^{1}$ The analytical distinction between unemployment and inactivity depends on the level of the benefits available and the eligibility criteria for whether individuals are defined as unemployed or out of the labour force (Black et al. 2002; Autor and Duggan 2003; Rege et al. 2009; Bratsberg et al. 2010). Some scholars have claimed that the distinction is vague and is strictly dependent on the institutional setting defined by the policies (Atkinson and Micklewright 1991). Given that our interest here is not to distinguish between different ways of not being engaged in paid work, but rather between working or not working and between different working hour arrangements, the categories unemployment and inactivity were combined.

${ }^{2}$ All of the analyses were performed using the software Stata14 and the Stata-package SPost13 (Long and Freese 2014).
} 
Table 7.1 Sample distribution, by migrant status, migrant generation and country of origin (column \%)

\begin{tabular}{|c|c|c|c|c|c|c|c|c|c|}
\hline & \multicolumn{2}{|c|}{ Migrant status } & \multicolumn{2}{|c|}{$\begin{array}{l}\text { Migrant } \\
\text { generation }\end{array}$} & \multicolumn{4}{|c|}{ Country of origin } & \multirow[b]{2}{*}{ Tot. } \\
\hline & \begin{tabular}{|l|}
$\begin{array}{l}\text { Non- } \\
\text { migrant }\end{array}$ \\
\end{tabular} & Migrant & 1 st & 2nd & $\begin{array}{l}\text { West } \\
\text { EU }\end{array}$ & \begin{tabular}{|l|} 
East \\
EU \\
\end{tabular} & \begin{tabular}{|l} 
South \\
EU
\end{tabular} & Oth. & \\
\hline \multicolumn{10}{|c|}{ Partnership status } \\
\hline $\begin{array}{l}\text { Mothers in } \\
\text { couples }\end{array}$ & 89.0 & 89.7 & 91.5 & 87.9 & 88.6 & 95.9 & 89.7 & 88.6 & 89.5 \\
\hline Lone mothers & 11.0 & 10.3 & 8.5 & 12.1 & 11.4 & 4.2 & 10.3 & 11.4 & 10.5 \\
\hline \multicolumn{10}{|c|}{ Employment status } \\
\hline $\begin{array}{l}\text { Out of } \\
\text { employment } \\
\text { (inactive/ } \\
\text { unemployed) }\end{array}$ & 20.9 & 27.9 & 36.4 & 19.4 & 25.6 & 36.5 & 19.8 & 41.4 & 25.2 \\
\hline Employed & 79.1 & 72.2 & 63.6 & 80.7 & 74.4 & 63.5 & 80.2 & 58.6 & 74.8 \\
\hline \multicolumn{10}{|l|}{ Working hours } \\
\hline $\begin{array}{l}\text { Out of } \\
\text { employment } \\
\text { (inactive/ } \\
\text { unemployed) }\end{array}$ & 20.9 & 27.9 & 36.4 & 19.4 & 25.6 & 36.5 & 19.8 & 41.4 & 25.2 \\
\hline Full time & 9.4 & 21.4 & 24.5 & 18.3 & 15.5 & 30.8 & 25.6 & 21.6 & 15.7 \\
\hline $\begin{array}{l}\text { Long part time } \\
(50-89 \%)\end{array}$ & 30.9 & 27.9 & 22.3 & 33.4 & 30.7 & 20.0 & 31.5 & 20.0 & 28.8 \\
\hline $\begin{array}{l}\text { Short part time } \\
(<50 \%)\end{array}$ & 38.8 & 23.0 & 16.9 & 29.0 & 28.1 & 12.6 & 23.1 & 17.0 & 30.3 \\
\hline \multicolumn{10}{|l|}{ Age } \\
\hline $20-29$ & 5.8 & 11.6 & 11.9 & 11.3 & 5.4 & 26.5 & 7.0 & 15.5 & 8.7 \\
\hline $30-36$ & 17.7 & 21.2 & 22.7 & 19.6 & 18.7 & 23.9 & 19.0 & 26.8 & 19.6 \\
\hline $36-44$ & 48.5 & 48.3 & 46.5 & 50.1 & 51.2 & 37.5 & 54.7 & 43.0 & 48.2 \\
\hline $45+$ & 28.1 & 19.0 & 19.0 & 19.0 & 24.8 & 12.1 & 19.3 & 14.8 & 23.6 \\
\hline \multicolumn{10}{|l|}{ Education } \\
\hline $\begin{array}{l}\text { Lower } \\
\text { secondary }\end{array}$ & 5.9 & 25.4 & 37.1 & 13.6 & 6.9 & 54.6 & 36.1 & 30.7 & 16.7 \\
\hline $\begin{array}{l}\text { Upper } \\
\text { secondary }\end{array}$ & 73.7 & 48.8 & 33.6 & 64.0 & 50.7 & 39.9 & 50.3 & 37.1 & 59.9 \\
\hline Tertiary & 20.4 & 25.9 & 29.4 & 22.4 & 42.4 & 5.5 & 13.6 & 32.2 & 23.4 \\
\hline \multicolumn{10}{|c|}{ Nr. of children below 18 in the household } \\
\hline 1 & 34.7 & 38.5 & 40.2 & 36.7 & 38.0 & 31.6 & 42.0 & 41.4 & 36.7 \\
\hline 2 & 46.1 & 46.5 & 44.0 & 49.0 & 46.7 & 40.9 & 48.6 & 45.6 & 46.0 \\
\hline $3+$ & 19.2 & 15.2 & 15.9 & 14.4 & 15.3 & 27.5 & 9.4 & 12.9 & 17.3 \\
\hline \multicolumn{10}{|c|}{ Presence of a child aged $0-2$} \\
\hline No & 79.0 & 76.5 & 75.0 & 77.9 & 77.2 & 75.7 & 81.3 & 69.3 & 77.6 \\
\hline Yes & 21.0 & 23.6 & 25.0 & 22.1 & 22.8 & 24.3 & 18.7 & 30.8 & 22.4 \\
\hline$N$ & 2197 & 4617 & 3252 & 1365 & 1593 & 788 & 1227 & 1009 & 6814 \\
\hline
\end{tabular}

Source: SLFS 2008 ( $\mathrm{N}=6814)$. Western Europe: Andorra, Austria, Belgium, Denmark, Finland, France, Germany, Great Britain, Ireland, Lietchtenstein, Luxemburg, Monaco, The Netherlands, Sweden; Eastern Europe: Albania, Bosnia, Croatia, Hungary, Kosovo, Makedonia, Montenegro, Poland, Romania, Serbia, Slovenia, Yugoslavia. Southern Europe: Chypre, Greece, Italy, Malta, Spain, Portugal 
tertiary degree). On average, the migrants had less education than the non-migrants; $94 \%$ of non-migrants, but only $75 \%$ of migrants had at least an upper-secondary degree. In terms of their marital status, the composition of the immigrant group was rather similar to that of the non-migrant group, with the majority of the women being married (about $80 \%$ ). The percentages of divorced women were rather similar as well (about 10\%). Only about $1 \%$ of the mothers in our sample were widowed; this suggests that most of the women who were lone mothers were divorced or had never been married, while very few were widows (because the amount of variation was small, marital status was not used in our multivariate analyses).

The second set of control variables referred to the children. These variables were a dummy for the presence of a child between zero and two years old in the household (yes/no), and a categorical variable for the number of children under age 18 in the household $(1,2$, or $3+)$. Overall, the number of children did not significantly vary by migrant status.

\section{Results}

\section{In and Out of Employment}

We start with a descriptive overview of the dichotomous variable on labour market participation (see Fig. 7.1). First, the share of women who were out of employment was more than twice as high among the mothers in couples as among the lone mothers (27\% versus $12 \%)$. This difference was significant not only in the bivariate statistics, but also in the multivariate statistics when all our control variables were added.

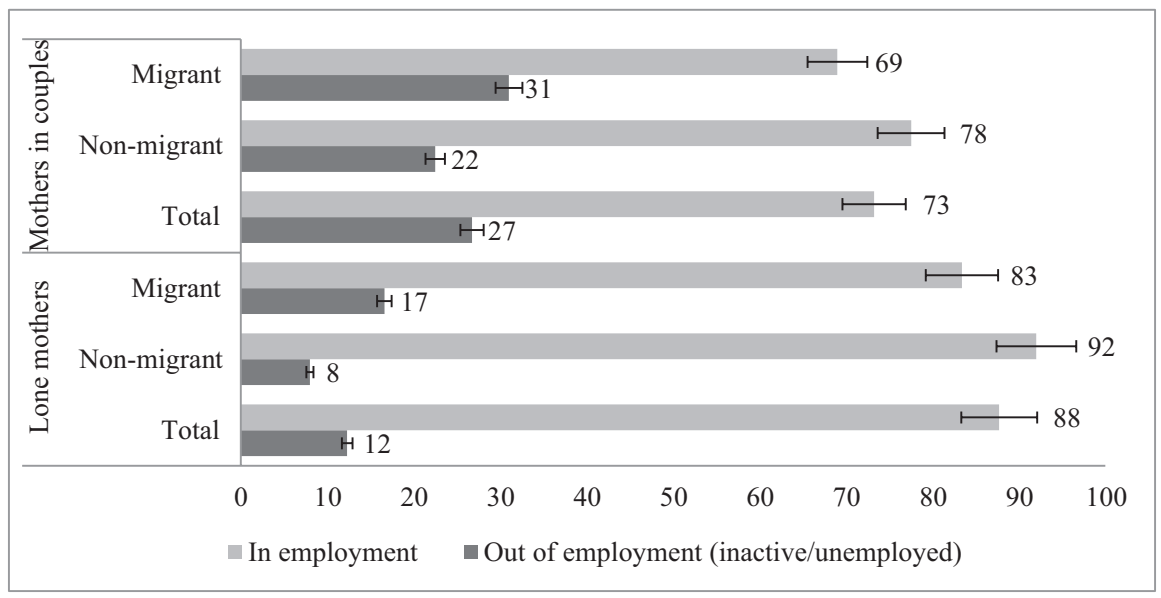

Fig. 7.1 Labour market participation by migrant status and partnership status. Source: SLFS 2008 $(\mathrm{N}=6814)$ 
(a)

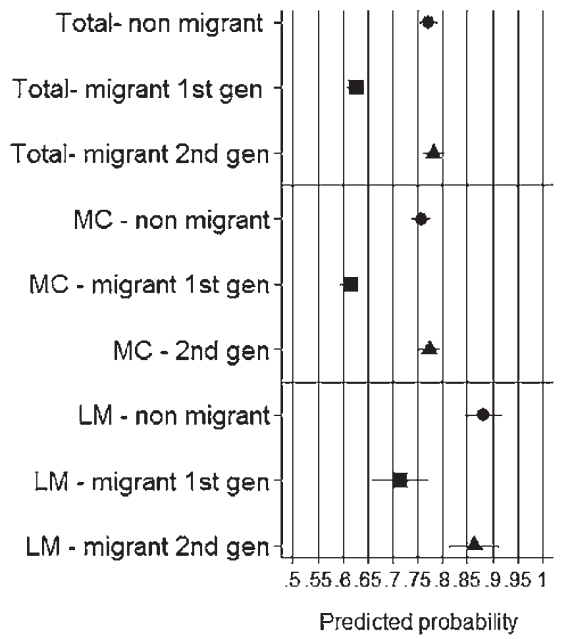

(b)

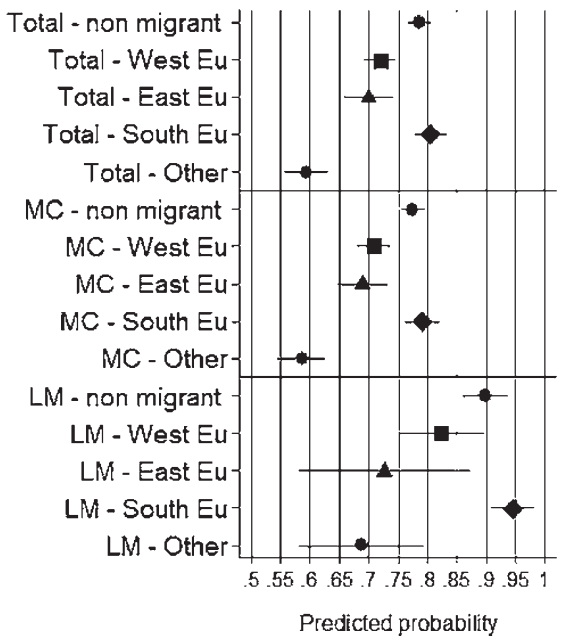

Fig. 7.2 Predicted probabilities of being in vs. out of employment, by partnership status and (a) migrant status, and (b) country of origin. Source: SLFS $2008(\mathrm{~N}=6814)$. LM = lone mothers, $\mathrm{MC}=$ mothers in couples. Estimates from logit regression models controlled for education, age, number of children under age 18 in the household, presence of a 0-2-year-old child in the household. Predicted probabilities for the controls are in the Appendix (Table 7.A1)

When we examined labour market participation levels by migrant status, we found that about $28 \%$ of the migrants and $21 \%$ of the non-migrants were out of employment (see Table 7.1). Figure 7.1 shows the results for the comparison between migrants and non-migrants by the mothers' partnership status: the pattern of lower non-employment levels among lone mothers than among mothers in couples was found for both the migrants and the non-migrants. Non-employment levels were higher for the migrants than for the non-migrants in both partnership-status groups: $17 \%$ of the lone mothers and $31 \%$ of the mothers in couples were not active on the labour market. These results remained significant in the multivariate models.

Although it was not within the scope of our paper, when we looked at the labour force participation levels of the women who had never had children or whose children had left the household we found more evidence to support the hypothesis of an immigrant disadvantage: $9 \%$ of the non-migrants and $20 \%$ of the migrants were out of employment ${ }^{3}$.

In the next step we inserted the control variables into multivariate models, and investigated the question of whether there was variation within the migrant group. Figure 7.2a displays the linear probability of being employed versus being out of employment by migrant generation and partnership status. On the one hand, even after controlling for the individual characteristics of the mothers and their children, differences by migrant status persisted. The probability of being employed was

${ }^{3}$ Results available upon request. 
rather similar for the second-generation migrants and the non-migrants: for each of these groups respectively, the probability of being employed was about $77 \%$ and $76 \%$ for the mothers in couples and about $88 \%$ and $86 \%$ for lone mothers. By contrast, for the first-generation migrants about $61 \%$ among the mothers in couples and about $72 \%$ of the lone mothers were employed. The differences between the first generation and their descendants and the non-migrants were between 10 and 15 percentage points, respectively. These differences were significant, and persist after we controlled for the characteristics of the mother and her household. On the other hand, we found clear differences in employment levels by partnership status for the first and second migrant generations, as well as for the non-migrants, with lone mothers again being more likely to be in employment than mothers in couples.

It is worth highlighting that country of origin represents a potential driver of differentiation. However, the relatively small sample size did not allow us to take into consideration migrant generation and country of origin in interaction. Nevertheless, we wanted to account for such a crucial dimension and we therefore estimated similar models distinguishing the migrants by their country of origin (Fig. 7.2b). Here we found differences of up to $15 \%$ in the FLFP of the lone mothers and the mothers in couples in nearly all groups. Compared to non-migrants, the differences by country of origin were mostly insignificant. All migrant groups had similar or lower probabilities of employment than non-migrants. For women from European countries these results may not be too surprising, as the differences between Switzerland and their respective country of origin may not be very large. However, the employment probabilities of migrants from countries outside of Europe were about $20 \%$ lower than for nonmigrants. This was a highly heterogeneous group, so our interpretation of these results is tentative. One possible explanation is that the largest proportion of migrant mothers in this group come from Turkey, where the FLFP is relatively low; thus, the results may reflect cultural differences in the FLFP in the country of origin.

\section{Working Hours}

The second part of our analyses accounted for the differentiation within employment by working hours; i.e., by full-time, long part-time, and short part-time employment. We display the results separately by partnership status and migrant generation (see Fig. 7.3a, b). The first conclusion from the Fig. 7.3a and 7.3b is that the lone mothers worked more full time or long part time than the mothers in couples, independently from their migrant status.

The second conclusion concerns the comparison between the migrant generations. Each of the three groups had distinct working hour patterns. Among the nonmigrants, only $8 \%$ of the mothers in couples and $19 \%$ of the lone mothers were in full-time employment; the lowest values in the sample. Among the first generation, $23 \%$ of the mothers in couples and $35 \%$ of lone mothers worked full time. The respective numbers for the second generation were $16 \%$ and $31 \%$. Among the mothers in couples, the likelihood of being in short or in long part-time employment was 
(a)

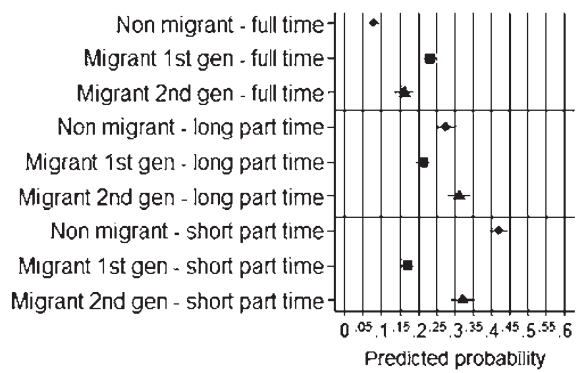

(b)

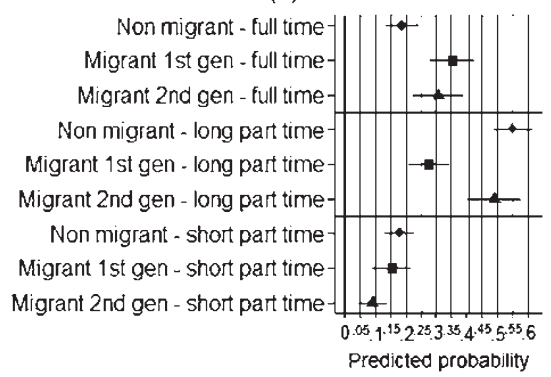

Fig. 7.3 Predicted probabilities for different labour market arrangements, by partnership status and migrant generation: (a) Mothers in couple, (b) Lone mothers. Source: SLFS 2008 (N = 6814). Note: Estimates from multinomial logit regression models controlling for education, age, number of children under age 18 in the household, presence of a 0-2-year-old child in the household. Predicted probabilities for the controls are displayed in the Appendix (Table 7.A2)

not statistically different. By contrast, the lone migrant mothers were the least likely to have been in short part-time employment, independently from the migrant generation to which they belonged.

Mothers in couples were the least likely to work both in full-time and long parttime employment, when the two forms of employment were added together. This difference was most pronounced among the non-migrants (almost 40\%), and it was smallest among the first generation (18\%). Since migrants had higher overall rates of full-time employment (63\% for the first and $80 \%$ for the second generation), this reduced the differences between lone mothers and mothers in couples among migrant mothers.

Differences in working hour patterns were consistent across the migrant groups by their country of origin (Fig. 7.4a, b). The mothers in couples of each of the country groups were more likely to have been in full-time or long part-time employment than the non-migrants, with values ranging from about $39 \%$ for the "other" migrants to $54 \%$ for the southern Europeans. For lone mothers, these numbers varied from $58 \%$ among the non-European group to 88\% among the southern European group. For all of the migrant groups short part time was the least common form of employment (the minimum was $14 \%$ of lone mothers from southern Europe).

\section{Effect of Control Variables}

Finally, we come back to the effects of the control variables of the mothers and their children. We assumed that any differences by migrant status and/or by partnership status would diminish or vanish when we inserted control variables into the models. In both analyses - the analysis on the binary indicator of employment versus out of employment and the analysis on the type of employment by working hours-the 
(a)

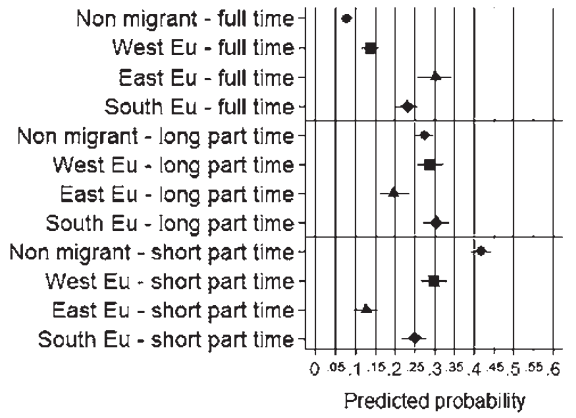

(b)

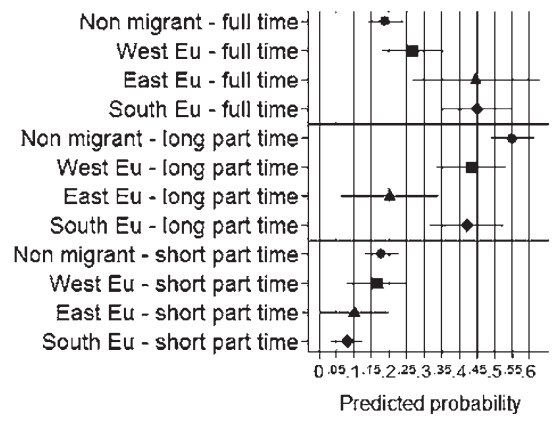

Fig. 7.4 Predicted probabilities for different labour market arrangements, by partnership status and country of origin: (a) Mothers in couple, (b) Lone mothers. Source: SLFS 2008 (N = 6814). Note: Estimates from multinomial logit regression models controlling for education, age, number of children under age 18 in the household, presence of a 0-2-year-old child in the household. Predicted probabilities for the controls are displayed in the Appendix (Table 7.A2)

control variables did not significantly change our results concerning the main effects; i.e., the differences in employment patterns remained between the lone mothers and the mothers in couples, as well as between the migrant generations and the non-migrants by country of origin. Our results on the effects of the control variables are consistent with the literature (see Tables 7.A1 and 7.A2 in the Appendix): the presence of a child up to age two decreased the probability of being employed by 11 percentage points. The more children in the household, the less likely the mother was to be engaged in paid work. The older the mother was and the higher her education was, the more likely she was to be active in the labour force (Table 7.A1).

\section{Discussion and Conclusions}

In this chapter, we drew attention to the labour market participation patterns of women in Switzerland by focusing on two risk factors: i.e., being an immigrant from abroad or a migrant descendant and lone motherhood. We assumed that these two factors contributed to higher non-employment rates and/or marginal working conditions, and formulated four working hypotheses. These hypotheses were tested using quantitative individual data from the Swiss Labour Force Survey 2008, which contained sufficient case numbers of both target groups, and allowed us to take into account the socio-demographic characteristics of the mothers and the information on their household composition in multivariate analyses.

Our first working hypothesis concerned the comparison between lone mothers and mothers in couples in terms of their labour force participation levels and employment hours. Our analyses provided mixed evidence on this issue. On the one hand, based on the assumptions derived from household specialization theory and 
from the (inadequate) family-work reconciliation policies in Switzerland, we had hypothesised that lone mothers would be more likely to be out of employment than mothers in couples. This hypothesis must be rejected, as we found that lone mothers were significantly more likely to be employed than mothers in couples. This finding was consistent in all of the estimations that took into account the control variables. On the other hand, we found that if lone mothers were employed, they worked longer working hours than mothers in couples. The most common forms of employment among lone mothers were full time and long part time.

We had based our second working hypothesis on the human-capital approach, and assumed that migrants would be disadvantaged on the labour market, and would thus have higher non-employment risks and longer working hours. When estimating these outcomes for all migrant mothers in total, our results confirmed both parts of this hypothesis. Regardless of their partnership status, compared to their nonmigrant counterparts migrants were significantly more likely to be out of employment, and, if active in the workforce, to be in full-time or long part-time employment.

These results confirmed our assumption that migrant lone mothers face multiple disadvantages. On the one hand, migrants are disadvantaged in terms of finding employment for a variety of reasons (e.g., their diploma or qualifications may not be recognised, they may be discriminated against by employers, or they may face limitations because of their residence permit); thus, when they find a job they may be less able to negotiate a part-time schedule that would help them reconcile their work and care responsibilities. On the other hand, a lone mother who provides the main income in the household may have few options other than to work full time, and may be less able to afford being out of employment or in a part-time job than a mother in a couple. Thus, for migrant lone mothers a double imperative seems to apply: they can either work full time if the income from work is sufficient to pay for external (expensive) care and sustain the household's costs, or they can live on social assistance if their prospects of finding gainful employment are gloomy. In the former case, the stresses associated with reconciling work and family may be greater than for mothers in couples, for whom working part time may provide a partial solution.

In further analyses we examined within-group variation among immigrants, thus providing evidence for our third hypothesis: i.e., we found that when we only considered being in or out of employment, women of the first migrant generation in particular were disadvantaged relative to non-migrants. The patterns of the second generation were not, however, significantly different from those of non-migrants. By contrast, when we analysed the type of employment, we found that the differences between first-generation migrants and non-migrants remained; i.e., that firstgeneration migrants had higher levels of non-employment and longer working hours. But the employment patterns of the second generation appeared to fall between those of the first generation and the non-migrants. These patterns were consistent in all of the models that took into account the control variables: in line with the literature, our results showed a strong immigrant disadvantage among firstgeneration migrants in particular, as well as evidence of adaptive processes and increasing integration among migrant descendants. But we also found that when 
two risk factors were combined-i.e., lone motherhood and migrant status - an additive disadvantage on the labour market emerged.

We also investigated within-group variation by country of origin. The results produced here were conclusive in that they showed that origin did not matter in addition to the migrant status, because the patterns were consistent across almost all of the groups. Ideally, we would have taken into account the migrant generation and the country of origin simultaneously, but the small sample size of these two risk groups did not allow us to do so. We therefore do not want to offer an interpretation of these results, other than to observe that the rather small differences found between the mostly European countries of origin may be reflected in the small amount of variation found among the immigrant groups as well. The differences between the European immigrants and the group of "other" migrants were slightly larger, but because this group was so heterogeneous we cannot draw any reliable conclusions here. Overall, it seems that migrant generation and partnership status are the factors that matter most for the labour market participation levels of immigrant women in Switzerland.

At this point, however, we return briefly to the fourth working hypothesis on the effect of compositional differences by the socio-demographic characteristics of the mothers and their children. Inserting these control variables did not significantly change our results: both the lone motherhood disadvantage and the migrant disadvantage remained prominent in our analyses. These results suggest that future research on women's labour force participation should take into account withingroup variation among mothers by their partnership status, as well as among migrants by accounting for migrant generation and country of origin.

Thus, our findings suggest that the common assumption that social protection measures tend to discourage LFP among lone mothers with unfavourable labour market prospects should be revised (Gangl 2006; Luijkx and Wolbers 2009; Dieckhoff 2011). Relative to the mothers in couples, the lone mothers in our sample were more likely to be in the labour market and to be working long hours. An open question for future research to investigate is the extent to which employment and working hour patterns relate differently to the health risks faced by both parents and children depending on whether they are migrants. For lone mothers, the positive association between employment and health may be weakened by the double burden of being the main earner and the main caregiver: flexible working hour arrangements could counterbalance the potential additional stress of being employed in the absence of work-family balance policies (see Struffolino et al. 2016 for a review). However, migrants may have limited access to such arrangements due to their segregation in specific labour market sectors.

In addition to other problematic issues connected to the status of migrants (e.g., insufficient language skills, below-average education and job qualifications, religious and non-religious forms of discrimination), difficulties in accessing child care may be one of the reasons why first-generation migrant mothers have a particularly high unemployment risk. They may have smaller support networks for child care than non-migrant lone mothers. Previous research has demonstrated that care of grandchildren is an important form of intergenerational support provided by the older generation to the younger generation. Especially when public child care is 
scarce or/and expensive, this type of support may be necessary for mothers to return to the labour market (Wheelock and Jones [2002] for England). Hank and Buber (2007) showed that child care provided by grandparents can reduce the costs of (women's) labour market engagement. This financial consideration may particularly relevant for migrant mothers, who often work in low-wage jobs. Thus, compared to non-migrant women, who can rely on help with child care from their own parents or their partner, migrant women, who often lack a supportive social network in the country of destination, may face additional challenges in returning to work, especially if they are not in a couple.

Acknowledgements This paper benefited from the support of the Swiss National Centre of Competence in Research LIVES - Overcoming Vulnerability: Life Course Perspectives, which is financed by the Swiss National Science Foundation (Grant number: 51NF40-160590).

\section{Appendix}

Table 7.A1 Predicted probabilities (PP) for being employed vs. not being in employment. 95\% confidence intervals $(\mathrm{CI})$

\begin{tabular}{l|l|l|l|l|l|l}
\hline & \multicolumn{5}{|l|}{ (a) Migrant status } & \multicolumn{3}{l}{ (b) Country of origin } & \\
\cline { 2 - 7 } & PP & CI min & CI max & PP & CI min & CI max \\
\hline Child aged 0-2 & & & & & & \\
\hline No & 0.73 & 0.72 & 0.75 & 0.77 & 0.76 & 0.78 \\
\hline Yes & 0.62 & 0.60 & 0.65 & 0.68 & 0.65 & 0.71 \\
\hline Nr.children $<18$ & & & & & & \\
\hline 1 & 0.74 & 0.72 & 0.76 & 0.78 & 0.76 & 0.80 \\
\hline 2 & 0.70 & 0.68 & 0.71 & 0.75 & 0.73 & 0.76 \\
\hline $3+$ & 0.64 & 0.61 & 0.66 & 0.69 & 0.65 & 0.72 \\
\hline Age & & & & & & \\
\hline $20-29$ & 0.65 & 0.61 & 0.69 & 0.73 & 0.69 & 0.78 \\
\hline $30-36$ & 0.69 & 0.67 & 0.71 & 0.71 & 0.69 & 0.74 \\
\hline $36-44$ & 0.72 & 0.71 & 0.74 & 0.76 & 0.74 & 0.77 \\
\hline $45+$ & 0.71 & 0.68 & 0.74 & 0.78 & 0.75 & 0.81 \\
\hline Education & & & & & & \\
\hline Lower secondary & 0.68 & 0.66 & 0.71 & 0.69 & 0.66 & 0.73 \\
\hline Upper secondary & 0.69 & 0.67 & 0.70 & 0.74 & 0.72 & 0.76 \\
\hline Tertiary & 0.75 & 0.73 & 0.77 & 0.81 & 0.79 & 0.83 \\
\hline
\end{tabular}

Note: Estimates from binary logit regression models. Model (a) controls for migrant status, model (b) controls for country of origin. SLFS $2008(\mathrm{~N}=6814)$. 
Table 7.A2 Predicted probabilities (PP) for the control variables for not being in employment or being in full-time or long or short part-time employment, by migrant status and partnership status (Fig. 7.3), and by country of origin and partnership status (Fig. 7.4). 95\% confidence intervals (CI)

\begin{tabular}{|c|c|c|c|c|c|c|c|c|c|c|c|}
\hline \multicolumn{3}{|c|}{$\begin{array}{l}\text { Out of } \\
\text { employment }\end{array}$} & \multicolumn{3}{|c|}{$\begin{array}{l}\text { Employed } \\
\text { full time }\end{array}$} & \multicolumn{3}{|c|}{$\begin{array}{l}\text { Employed long } \\
\text { part time } \\
(50-89 \%)\end{array}$} & \multicolumn{3}{|c|}{$\begin{array}{l}\text { Employed short } \\
\text { part time }(<50 \%)\end{array}$} \\
\hline PP & $\begin{array}{l}\text { CI } \\
\min \end{array}$ & $\begin{array}{l}\mathrm{CI} \\
\max \end{array}$ & PP & $\begin{array}{l}\text { CI } \\
\text { min }\end{array}$ & $\begin{array}{l}\text { CI } \\
\max \end{array}$ & PP & $\begin{array}{l}\mathrm{CI} \\
\min \end{array}$ & $\begin{array}{l}\text { CI } \\
\max \end{array}$ & $\mathrm{PP}$ & $\begin{array}{l}\mathrm{CI} \\
\min \end{array}$ & $\begin{array}{l}\mathrm{CI} \\
\max \end{array}$ \\
\hline
\end{tabular}

Figure 7.3

Child aged 0-2

\begin{tabular}{|c|c|c|c|c|c|c|c|c|c|c|c|c|}
\hline No & 0.23 & 0.22 & 0.25 & 0.17 & 0.15 & 0.18 & 0.29 & 0.28 & 0.31 & 0.31 & 0.29 & 0.33 \\
\hline Yes & 0.32 & 0.29 & 0.35 & 0.13 & 0.11 & 0.15 & 0.27 & 0.24 & 0.30 & 0.29 & 0.26 & 0.32 \\
\hline \multicolumn{13}{|c|}{ Nr. children $<18$} \\
\hline 1 & 0.22 & 0.20 & 0.24 & 0.21 & 0.19 & 0.22 & 0.32 & 0.30 & 0.35 & 0.25 & 0.23 & 0.28 \\
\hline 2 & 0.26 & 0.24 & 0.27 & 0.13 & 0.12 & 0.15 & 0.29 & 0.27 & 0.31 & 0.33 & 0.31 & 0.35 \\
\hline $3+$ & 0.32 & 0.29 & 0.35 & 0.11 & 0.09 & 0.14 & 0.22 & 0.19 & 0.25 & 0.35 & 0.31 & 0.38 \\
\hline \multicolumn{13}{|l|}{ Age } \\
\hline $20-29$ & 0.29 & 0.24 & 0.33 & 0.19 & 0.15 & 0.24 & 0.21 & 0.17 & 0.26 & 0.30 & 0.25 & 0.36 \\
\hline $30-36$ & 0.29 & 0.26 & 0.32 & 0.17 & 0.15 & 0.19 & 0.25 & 0.23 & 0.28 & 0.28 & 0.26 & 0.31 \\
\hline $36-44$ & 0.24 & 0.23 & 0.26 & 0.15 & 0.14 & 0.17 & 0.29 & 0.27 & 0.31 & 0.32 & 0.30 & 0.34 \\
\hline $45+$ & 0.22 & 0.19 & 0.25 & 0.14 & 0.12 & 0.17 & 0.34 & 0.31 & 0.38 & 0.30 & 0.26 & 0.33 \\
\hline \multicolumn{13}{|c|}{ Education } \\
\hline $\begin{array}{l}\text { Lower } \\
\text { sec. }\end{array}$ & 0.28 & 0.25 & 0.32 & 0.21 & 0.19 & 0.24 & 0.25 & 0.21 & 0.28 & 0.26 & 0.23 & 0.29 \\
\hline $\begin{array}{l}\text { Upper } \\
\text { sec. }\end{array}$ & 0.27 & 0.25 & 0.29 & 0.14 & 0.13 & 0.15 & 0.27 & 0.25 & 0.28 & 0.32 & 0.31 & 0.34 \\
\hline Tertiary & 0.19 & 0.17 & 0.21 & 0.15 & 0.13 & 0.17 & 0.38 & 0.35 & 0.41 & 0.27 & 0.25 & 0.30 \\
\hline
\end{tabular}

Figure $\mathbf{7 . 4}$

Child aged 0-2

\begin{tabular}{l|l|l|l|l|l|l|l|l|l|l|l|l}
\hline No & 0.23 & 0.22 & 0.24 & 0.16 & 0.15 & 0.18 & 0.29 & 0.28 & 0.31 & 0.31 & 0.30 & 0.33 \\
\hline Yes & 0.32 & 0.29 & 0.35 & 0.13 & 0.11 & 0.15 & 0.27 & 0.24 & 0.30 & 0.28 & 0.25 & 0.31 \\
\hline Nr. children $<18$ \\
\hline 1 & 0.22 & 0.20 & 0.24 & 0.21 & 0.19 & 0.23 & 0.32 & 0.30 & 0.35 & 0.25 & 0.23 & 0.28 \\
\hline 2 & 0.25 & 0.24 & 0.27 & 0.13 & 0.12 & 0.15 & 0.29 & 0.27 & 0.31 & 0.33 & 0.31 & 0.35 \\
\hline $3+$ & 0.32 & 0.29 & 0.35 & 0.11 & 0.09 & 0.13 & 0.22 & 0.19 & 0.25 & 0.35 & 0.32 & 0.39 \\
\hline Age & 0.27 & 0.23 & 0.31 & 0.18 & 0.14 & 0.22 & 0.22 & 0.17 & 0.27 & 0.33 & 0.28 & 0.39 \\
\hline $20-29$ & 0.29 & 0.26 & 0.32 & 0.17 & 0.15 & 0.19 & 0.25 & 0.23 & 0.28 & 0.29 & 0.26 & 0.32 \\
\hline $30-36$ & 0.29 & 0.25 & 0.26 & 0.16 & 0.14 & 0.17 & 0.29 & 0.27 & 0.31 & 0.31 & 0.30 & 0.33 \\
\hline $36-44$ & 0.25 & 0.23 & 0.17 & 0.12 \\
\hline $45+$ & 0.22 & 0.19 & 0.25 & 0.15 & 0.12 & 0.17 & 0.34 & 0.31 & 0.37 & 0.29 & 0.26 & 0.32 \\
\hline
\end{tabular}


Table 7.A2 (continued)

\begin{tabular}{|c|c|c|c|c|c|c|c|c|c|c|c|c|}
\hline & \multicolumn{3}{|c|}{$\begin{array}{l}\text { Out of } \\
\text { employment }\end{array}$} & \multicolumn{3}{|c|}{$\begin{array}{l}\text { Employed } \\
\text { full time }\end{array}$} & \multicolumn{3}{|c|}{$\begin{array}{l}\text { Employed long } \\
\text { part time } \\
(50-89 \%)\end{array}$} & \multicolumn{3}{|c|}{$\begin{array}{l}\text { Employed short } \\
\text { part time }(<50 \%)\end{array}$} \\
\hline & PP & $\begin{array}{l}\mathrm{CI} \\
\mathrm{min}\end{array}$ & $\begin{array}{l}\text { CI } \\
\max \end{array}$ & PP & $\begin{array}{l}\mathrm{CI} \\
\min \end{array}$ & $\begin{array}{l}\mathrm{CI} \\
\max \end{array}$ & PP & \begin{tabular}{|l|}
$\mathrm{CI}$ \\
$\mathrm{min}$
\end{tabular} & $\begin{array}{l}\text { CI } \\
\max \end{array}$ & PP & $\begin{array}{l}\mathrm{CI} \\
\mathrm{min}\end{array}$ & $\begin{array}{l}\text { CI } \\
\max \end{array}$ \\
\hline \multicolumn{13}{|c|}{ Education } \\
\hline $\begin{array}{l}\text { Lower } \\
\text { sec. }\end{array}$ & 0.32 & 0.28 & 0.35 & 0.20 & 0.17 & 0.22 & 0.22 & 0.19 & 0.26 & 0.27 & 0.23 & 0.30 \\
\hline $\begin{array}{l}\text { Upper } \\
\text { sec. }\end{array}$ & 0.26 & 0.25 & 0.28 & 0.14 & 0.13 & 0.15 & 0.27 & 0.25 & 0.29 & 0.33 & 0.31 & 0.35 \\
\hline Tertiary & 0.19 & 0.17 & 0.21 & 0.16 & 0.14 & 0.18 & 0.39 & 0.36 & 0.42 & 0.26 & 0.23 & 0.29 \\
\hline
\end{tabular}

Note: Estimates from multinomial logit regression models. SLFS $2008(\mathrm{~N}=6814)$

\section{References}

Afonso, A. (2004). Immigration and its impacts in Switzerland. In N. Stavrou (Ed.), People on the move: The security, social, and economic implications of mass migration (pp. 147-166). Durham: Duke University Press.

Algan, Y., Dustmann, C., Glitz, A., \& Manning, A. (2010). The economic situation of first and second-generation immigrants in France, Germany and the United Kingdom. The Economic Journal, 120, 4-30.

Antecol, H. (2000). An examination of cross-country differences in the gender gap in labour force participation rates. Labour Economics, 7(4), 409-426.

Armingeon, K., Bertozzi, F., \& Bonoli, G. (2004). Swiss worlds of welfare. West European Politics, 27(1), 20-44.

Atkinson, A. B., \& Micklewright, J. (1991). Unemployment compensation and labour market transitions: A critical review. Journal of Economic Literature, 29(4), 1679-1727.

Autor, D. H., \& Duggan, M. G. (2003). The rise in the disability rolls and the decline in unemployment. The Quarterly Journal of Economics, 118(1), 157-206.

Baker, D., North, K., Alspac, T., \& Team, S. (1999). Does employment improve the health of lone mothers? Social Sciences and Medicine, 49(1), 121-131.

Becker, G. S. (1991). A treatise on the family (2nd ed.). Cambridge, MA: Harvard University Press.

Becker, G. S. (1993). Human capital: A theoretical and empirical analysis, with special reference to education. Chicago: University of Chicago Press. [1st ed., 1964].

Bertozzi, F., Bonoli, G., \& Gay-Des-Combes, B. (2005). La réforme de l'état social en Suisse. Presse politechnique et universitaires romandes.

Black, D., Daniel, K., \& Sanders, S. (2002). The impact of economic conditions on participation in disability programs: Evidence from the coal boom and bust. American Economic Review, 92(1), 27-50.

Blau, F. D., Kahn, L. M., Liu, A. Y.-H., \& Papps, K. L. (2013). The transmission of women's fertility, human capital, and work orientation across immigrant generations. Journal of Population Economics, 26(2), 405-435.

Boeckmann, I., Misra, J., \& Budig, M. (2015). Cultural and institutional factors shaping mothers' employment and working hours in postindustrial countries. Social Forces, 3(4), 1301-1333.

Branger, K., (2003). Cumul des désavantages. In: OFS. Vers l'égalité? Troisième rapport statistique, 161-189.

Bratsberg, B., Fevang, E., \& Røed, K. (2010). Disability in the welfare state: An unemployment problem in disguise? IZA Discussion Paper, 4897. 
Bühler, E. (2002). Atlas suisse des femmes et de l'égalité. Zürich: Seismo.

Bühlmann, F., Schmid Botkine, C., Farago, P., Höpflinger, F., Joye, D., Levy, R., Perrig-Chiello, P., \& Suter, C. (2012, October). Rapport social: générations en jeu. Zurich: Seismo.

Bütler, M., \& Ruesch, M. (2007). Annuities in Switzerland, Policy Research Working Paper. Washington, DC: World Bank, Financial Systems Department, Financial Policy Division.

Charsley, K. (2012). Transnational marriage. In K. Charsley (Ed.), Transnational marriage, New perspectives from Europe and beyond (pp. 3-22). New York: Routledge.

Chiswick, B. R. (1978). The effect of Americanization on the earnings of foreign-born men. Journal of Political Economy, 86, 897-921.

Constant, A., \& Massey, D. S. (2005). Labour market segmentation and the earnings of German guestworkers. Population Research and Policy Review, 24, 489-512.

de Coulon, A. (2003). Wage differentials between ethnic groups in Switzerland. Labour, 15(1), 111-132.

de Valk, H. A. G., \& Milewski, N. (2011). Family life transitions among children of immigrants: An introduction. Advances in Life Course Research, 16(4), 145-151. https://doi.org/10.1016/j. alcr.2011.10.001.

Dieckhoff, M. (2011). The effect of unemployment on subsequent job quality in Europe: A comparative study of four countries. Acta Sociologica, 54(3), 233-249.

Duleep, H. O. (1998). The family investment model: A formalization and review of evidence across immigrant groups. Gender Issues, 16, 84-104.

Fibbi, R., \& Wanner, P. (2009). Children of immigrant families in Switzerland: On a path between discrimination and integration (pp. 2009-2017). New York: Unicef, Innocenti Working Paper.

Flückiger, Y. (1998). The labour market in Switzerland: The end of a special case? International Journal of Manpower, 19(6), 369-395.

FSO - Federal Statistical Office. (2013). Labour market indicators for 2013. Neuchâtel: FSO.

FSO - Federal Statistical Office. (2015). Switzerland's population. Report number 1155-1500. Neuchâtel: FSO.

Gangl, M. (2006). Scar effects of unemployment: An assessment of institutional complementarities. American Sociological Review, 71(6), 986-1013.

Gebel, M. (2013). Is a temporary job better than unemployment? A cross-country comparison based on British, German, and Swiss panel data, SOEP papers on multidisciplinary panel data research, 543. Berlin: DIW.

Giraud, I. O., \& Lucas, B. (2009). Le renouveau des régimes de genre en Allemagne et en Suisse. Cahiers du Genre, 46(1), 17-46. https://doi.org/10.3917/cdge.046.0017.

Guarin, E., \& Rousseaux, E. (forthcoming). Labour market insertion risk factors for second-generation immigrants in Switzerland. In C. Bolzmann, L. Bernardi, \& J. M. Le Goff (Eds.), Situating children of migrants across borders and origins: A methodological overview. Berlin: Springer.

Han, P. (2003). Frauen und Migration: Strukturelle Bedingungen, Fakten und soziale Folgen der Frauenmigration. Stuttgart: Lucius \& Lucius.

Hank, K., \& Buber, I. (2007). Grandparents caring for their grandchildren: Findings from the 2004 survey of health, ageing and retirement in Europe. Mannheim: Research Institute for the Economics of Aging.

Höhne, J., \& Koopmans, R. (2010, February). Host-country cultural capital and labour market trajectories of migrants in Germany. WZB Discussion Paper Order no.: SP IV 2010-701. Berlin: Wissenschaftszentrum Berlin für Sozialforschung.

Kalter, F. (2008). Ethnische Ungleichheit auf dem Arbeitsmarkt. In M. Abraham \& T. Hinz (Eds.), Arbeitsmarktsoziologie. Probleme, Theorien, empirische Befunde (2nd ed., pp. 303-332). VS Verlag für Sozialwissenschaften: Wiesbaden.

Kulu, H., \& González-Ferrer, A. (2014). Family dynamics among immigrants and their descendants in Europe: Current research and opportunities. European Journal of Population, 30(4), 411-435.

Laganà, F., Chevillard, J., \& Gauthier, J.-A. (2014). Socioeconomic background and early postcompulsory education pathways: A comparison between natives and second-generation immigrants in Switzerland. European Sociological Review, 30(1), 18-34. 
Liebig, T., Kohls, S., \& Krause, K. (2012). The labour market integration of immigrants and their children in Switzerland. OECD Social, Employment and Migration Working Papers No. 128, Directorate for Employment, Labour and Social Affairs, OECD Publishing.

Lin, N. (1999). Social networks and status attainment. Annual Review of Sociology, 25, 467-487.

Long, J. E. (1980). The effect of americanization on earnings: Some evidence for women. Journal of Political Economy, 88, 620-629.

Long, J. S., \& Freese, J. (2014). Regression models for categorical dependent variables using Stata (3rd ed.p. 589). College Station: Stata Press.

Luijkx, R., \& Wolbers, M. H. J. (2009, February 3). The effects of non-employment in early worklife on subsequent employment chances of individuals in The Netherlands. European Sociological Review.

Lutz, H. (2007). Vom Weltmarkt in den Privathaushalt. Die neuen Dienstmädchen im Zeitalter der Globalisierung. Opladen: Barbara Budrich.

Milewski, N. (2013). Erwerbsbeteiligung und Einstellungen zur Familie von türkischen Migrantinnen im Generationenvergleich. Zeitschrift für Familienforschung, 25(1), 53-74.

Milewski, N., \& Kulu, H. (2014). Mixed marriages in Germany: A high risk of divorce for immigrant-native couples. European Journal of Population, 30(1), 89-113. https://doi.org/10.1007/ s10680-013-9298-1.

Monnier, A. (2006). Démographie contemporaine de l'Europe. Evolutions, tendances, défis. Paris: Arnand Colin.

OECD. (2015). OECD economic surveys: Switzerland 2015. Paris: OECD Publishing.

Pries, L. (2010). Internationale migration (3rd ed.). Bielefeld: transcript.

Rege, M., Telle, K., \& Votruba, M. (2009). The effect of plant downsizing on disability pension utilization. Journal of the European Economic Association, 7(4), 754-785.

Reimers, C. W. (1985). Cultural differences in labour force participation among married women. American Economic Review, 75(2), 251-255.

Rendall, M. S., Tsang, F., Rubin, J. K., Rabinovich, L., \& Janta, B. (2010). Contrasting trajectories of labour-market integration between migrant women in western and southern Europe. European Journal of Population, 26, 383-410.

Riaño, Y., \& Baghdadi, N. (2007). Understanding the labour market participation of skilled immigrant women in Switzerland: The interplay of class, ethnicity and gender. Journal of International Migration and Integration, 8(2), 163-183.

Rumbaut, R. G. (2004). Ages, life stages, and generational cohorts: Decomposing the immigrant first and second generations in the United States. International Migration Review, 38(3), $1160-1205$.

Salter, E. (2017). A media discourse analysis of lone parents in the UK: Investigating the stereotype. In L. Bernardi \& D. Mortelmans (Eds.), Lone parenthood - New insights in the life courses of single mothers and fathers. Berlin: Springer.

Staat, M., \& Wagenhals, G. (1996). Lone mothers: A review. Journal of Population Economics, 9(2), 131-140.

Struffolino, E., \& Bernardi, L. (2016). Lone mothers with children: Continuity and change over time. In: Demos. Family, migration. Demographic information No. 1 June 2016 (pp. 2-4). Neuchâtel: FSO.

Struffolino, E., Bernardi, L., \& Voorpostel, M. (2016). Self-reported health among lone mothers in Switzerland: Do employment and education matter? Population-E, 71(2), 187-214. https://doi. org/10.3917/pope.1602.0187.

Stutz, H., \& Knupfer, C. (2012). La protection sociale du travail de care non rémunéré. Les besoins d'adaptation de l'état social liés à l'évolution du partage du travail entre femmes et hommes. Bureau fédéral pour l'égalité entre femmes et hommes BFEG.

van Tubergen, F. (2008). The impact of the partner on the economic incorporation of immigrants. Household specialization or social capital? In F. Kalter (Ed.), Migration und Integration (pp. 307-324). Wiesbaden: VS Verlag für Sozialwissenschaften (Kölner Zeitschrift für Soziologie und Sozialpsychologie, Sonderheft 48). 
Wheelock, J., \& Jones, K. (2002). "Grandparents are the next best thing": Informal childcare for workings parents in urban Britain. Journal of Social Policy, 31(3), 441-463.

Winkelmann, R. (2002). Work and health in Switzerland: Immigrants and natives (SOI - Working Papers 0203), Socioeconomic Institute - University of Zurich.

Wooldridge, J. M. (2002). Econometric analysis of cross section and panel data. Cambridge/ London: MIT Press.

Zagel, H. (2014). Are all single mothers the same? Evidence from British and west German women's employment trajectories. European Sociological Review, 1(30), 49-63.

Nadja Milewski is Assistant Professor for Demography at the Institute for Sociology and Demography at the University of Rostock, Germany. Her research centres on demographic behaviour and life courses of international migrants, i.e., fertility and family dynamics, labour force participation and gender roles, as well as health and morbidity.

Emanuela Struffolino Emanuela Struffolino is senior researcher at the "Demography and Inequality" research group at the WZB Berlin Social Science Center and at the chair of Microsociology at the Humboldt University of Berlin, Germany. She obtained her $\mathrm{PhD}$ in Sociology at the University of Milano-Bicocca, Italy, and worked as research fellow at the Swiss NCCR program "LIVES overcoming vulnerability: life course perspectives". Her research interests include life-course sociology, gender inequalities in the labour market, social stratification, and methods for longitudinal data.

Laura Bernardi is Professor of Life Course Demography and Sociology at the Faculty of Social and Political Sciences at the University of Lausanne, Switzerland, and Deputy Director of the Swiss National Center for Competence in Research LIVES. Her major research areas are fertility, family demography, migration and life course. She has published in major sociological and demographic journals on topics like fertility intentions and behaviour, social network influences on family development, intergenerational transmission of fertility and family formation, lone parenthood and health, migration and family formation. She is also co-editing the Springer series on Life Course and Social Policies.

Open Access This chapter is licensed under the terms of the Creative Commons Attribution 4.0 International License (http://creativecommons.org/licenses/by/4.0/), which permits use, sharing, adaptation, distribution and reproduction in any medium or format, as long as you give appropriate credit to the original author(s) and the source, provide a link to the Creative Commons license and indicate if changes were made.

The images or other third party material in this chapter are included in the chapter's Creative Commons license, unless indicated otherwise in a credit line to the material. If material is not included in the chapter's Creative Commons license and your intended use is not permitted by statutory regulation or exceeds the permitted use, you will need to obtain permission directly from the copyright holder.

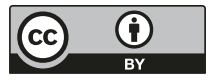

